\title{
MODEL OF COMPETENCY DEVELOPMENT IN THE PERSONALITY OF ENGLISH TEACHER CANDIDATES THROUGH STUDENT DEVELOPMENT MANAGEMENT BASED ON ISLAMIC ACADEMIC CULTURE
}

\author{
Nuridin ${ }^{1}{ }^{*}$ Choiril Anwar ${ }^{2}$ \\ Faculty of Teacher Training E Education Science, Universitas Islam Sultan Agung'; \\ Language and Communication Science Faculty, Universitas Islam Sultan Agung 2 \\ *Corresponding email: choirilanwar@unissula.ac.id
}

\begin{abstract}
The English Language Education Study Program of Sultan Agung Islamic University (Unissula) has formulated a vision to become a leading study program in building the generation of khaira ummah, developing science and technology on the basis of Islamic values, and building Islamic civilization towards a prosperous society blessed by Allah. The effort to realize this vision was carried out through the implementation of Islamic Academic Culture as an implementation of fostering students who gave birth to the best generation. This study aims to (1) find a student development management model based on Islamic Academic Culture at Sultan Agung Islamic University, (2) find a model of personality development competence in English Education Study Program students as prospective teachers. This research was conducted at Sultan Agung Islamic University. The study population was students of the English Language Study Program, Dean and Deputy Dean of Academic and Student Affairs. Data were collected through interviews, questionnaires and documentation. Data then were analyzed by descriptive analysis. The results of the study show that (1) The factual model that has been carried out by Unissula in student development is based on three guidelines in its management, namely Unissula's vision, Unissula's Strategic Plan (Renstra), and Islamic Academic Culture values. The student development program is generally carried out through three stages, namely the initial stage when new students enter, coaching is done through the Pekan Taaruf program, the second stage, when becoming a student, guidance is carried out through tutorials, reasoning, leadership, entrepreneurship, and interest-sharing programs. talent. In the third stage of training before graduation students, it is conducted through a debriefing program; (2) the model of Islamic Academic Culture-based student development is effectively used in an effort to
\end{abstract}


improve the personal competence of English Education Study Program students.

Keywords: personality competence, management, student development, Islamic academic culture

\section{INTRODUCTION}

Many practitioners of higher education in Western universities have expressed their concern for the modern Western education system. Prof. Harry Lewis, a Harvard professor for 32 years and served as Dean of Harvard College for 8 years (1995-2003), for example, expressed this concern in his book, Excellence without a Soul: How a Great University Forgot Education. According to Lewis (2006), the education system has made moral errors which erode the moral-spiritual side of man. This error is clearly reflected in the loss of a serious moral vision, which results in education becoming soulless education.

This kind of criticism has also been done by some Western scholars before, such as Sir Walter Moberly in his book The Crisis in the University, which was published in 1949; and Christopher Dawson in his book entitled The Crisis of Western Education, in 1961.

Ideally, educational genealogy should start from a philosophy about the importance of humans having good manners or behavior and developing various potentials to create a civilized system of life (Nuridin, 2015). The key to success in attempting adab (integrity) or the formation of good (dominant) behavior lies with the teacher, because the teacher is the spearhead of the success of education and is considered a figure who plays an important role in achieving educational goals (Wahab, 2011). Therefore, the most important factor of a teacher's figure is his maturity or personality (Sardiman AM, 2007).

The formation of the teacher's personality is not instant. Personality is formed through a long and continuous process. Efforts to establish teacher personality can be done when they are still students through student development efforts. This is important because at the level of reality, many events are of concern in the world of education, especially related to delinquency of students and students who show significant escalation from year to year (Nasikhah, 2013).

Student mischief in question is of various types. For example, the results of the 2011 National Narcotics Agency (BNN) survey showed that of 100 students there were two people who had tried using drugs, one of whom was a perpetrator of regular abuse. Furthermore, from 1,000 students, there are predicted to be around four non-injecting addicts and three injecting addicts (BNN, 2011). 
The research conducted by Simbolon (2012) in a boarding university in Bandung showed that there were data ranging from one to two cases of violence in the dormitory every semester, with the number of bullying perpetrators ranging from one to eight people.

Therefore, efforts to establish the personality of students, especially students of English education study program as prospective teachers, are very strategic. This strategic step is also an effort to realize the achievement of teacher personality competencies as regulated in Law Number 14 of 2005 on Teachers and Lecturers and Government Regulation (PP) Number 74 of 2008 on Teachers.

The problem is that personality competence is less developed through education in the classroom, because so far personality competencies have almost developed automatically in the frame of "religious values" and "Eastern values" of our nation which sometimes do not survive the current of modernization and globalization (Abdurrahman, 2007).

As an illustration, in the United States, personality development for teacher education is included in the curriculum with significant credits, given during the first two years in the prospective teacher education institution. Likewise in South Korea and Singapore, to ensure the personal competence of teachers they carry out a series of quality control activities to develop teacher competencies, and the development of personality competencies is given in a very large portion compared to other competencies (Iswanti, 2017).

Strategic steps to prepare prospective teachers who have personality competencies have been carried out by Sultan Agung Islamic University (Unissula). As the organizer of the English Language Education Study Program, Unissula has formulated a vision to become a leading islamic university in building the generation of khaira ummah, developing science and technology on the basis of islamic values, and developing islamic civilization towards a prosperous society blessed by Allah SWT (Statute of Unissula, 2011). In order to realize this vision, Unissula has implemented Islamic Academic Culture as the basis of the educational process, including in student development.

This article will describe the efforts that have been made by Unissula in order to prepare prospective teachers to have personality competencies through student development based on Islamic Academic Culture.

Teachers are professional educators with the main task of educating, teaching, guiding, directing, training, evaluating, and evaluating students in early childhood education in formal education, basic education, and secondary education (PP No. 74/2008 section 1 number 1) . Teachers must have academic qualifications, competencies, educator certificates, physical and spiritual health, and have the ability to realize national education goals 
(Section 2). Competence is a set of knowledge, skills, and behaviors that must be owned, internalized, mastered, and actualized by the teacher in carrying out professional duties (Section 2 paragraph 1). (2) Teacher competencies as referred to in paragraph 1 include pedagogical competencies, personality competencies, social competencies, and professional competencies obtained through professional education. (3) Teacher competence as referred to in paragraph 2 is holistic. Personality competencies as referred to in paragraph 2 at least include personalities that are: a) faithful and pious, b) noble, c) wise and wise, d) democratic, e) steady, f) authoritative, g) stable, h) mature, i) honest, j) sportsmanship, k) be an example for students and society, l) objectively evaluate their own performance, and $\mathrm{m}$ ) develop themselves independently and sustainably (paragraph 4).

Permendiknas No. 16 of 2007 concerning Qualifications and Competencies Teachers explain personality competencies for classroom teachers and subject teachers, at all levels of primary and secondary education, as follows:

1. Acting in accordance with the norms of religion, law, social and national culture of Indonesia, including: (a) respecting students without distinguishing adherents, tribes, customs, regions of origin and gender; and (b) behave according to the religious, legal and social norms that apply in society, and a diverse Indonesian national culture.

2. Showing himself/herself as an honest, noble person, and role model for students and society, including: (a) behaving honestly, decisively, and humanely; (b) behave that reflects noble piety and character; and (c) behavior that can be imitated by students and members of the surrounding community.

3. Showing himself as a solid, stable, mature, wise and authoritative person, including: (a) presenting himself as a stable and stable person; and (b) presenting himself as mature, wise and authoritative.

4. Demonstrating work ethic, high responsibility, pride in being a teacher, and self-confidence, including: (a) demonstrating high work ethic and responsibility; (b) proud of being a teacher and confident; and (c) work independently and professionally.

5. Upholding the professional code of ethics of the teacher, including: (a) understanding the professional code of ethics of the teacher; (b) applying the teacher professional code of ethics; and (c) behaving in accordance with the teacher's code of ethics.

Mastery of teacher personality competencies has important meaning, both for the teacher, school and especially for students. Scientific evidence as quoted by Sudradjat (2012) shows that teacher personality competencies 
influence student's learning and personality development. Quantitative studies conducted by Irawan (2010) prove that teacher personality competencies have a close and significant relationship with student achievement motivation. While the qualitative study conducted by Rahayu (2007) shows that teacher personality competence has a contribution to the moral condition of students. The results of other studies prove the appearance of the teacher's personality will more influence the interests and enthusiasm of children in participating in learning activities.

Personality competency becomes an important pillar for a teacher. Therefore, strengthening this competency needs to be done from the beginning, while still in the process of learning, as a university student (prospective teacher). The basic ability of professionalism, especially in the aspects of the teacher's personal competence needs to be well prepared.

Student Coaching Management

a. Management

The nature of management is al-tadbir (arrangement) (Ramayulis, 2008). This word is a derivation of the word dabbara (set) which is widely found in the Qur'an like the word of Allah SWT which means: "He governs affairs from heaven to earth, then (affairs) rises to him in one day whose levels are a thousand years according your calculations (Surah Al Sajdah: 05).

While management according to the term is the process of coordinating work activities so that it can be completed efficiently and effectively with and through other people (Robbin \& Coulter, 2007). Siagian (1980) defines management as the ability or skill to obtain an outcome in order to achieve goals through the activities of others.

Management is an activity process that must be carried out using scientific and practical ways of thinking to achieve the stated goals through the collaboration of other people by using available resources in the right way.

Terry (2006) suggests that basic elements which are available resources to achieve goals in management are man, machine, methods, and materials. In addition to the five elements above, there is the sixth element of management, namely market. These management elements are usually known as "6 $\mathrm{M}$ in management".

Activities to optimize the elements and resources possessed in management are carried out through planning to an evaluation process known as management functions. The management functions are designing, organizing, implementing, coordinating, and controlling. As Robbin \& Coulter (2007) stated that the most important basic function of management is planning, organizing, leading, and controlling. 


\section{b. Student Coaching}

Coaching is an effort of actions and activities carried out in an efficient manner to get better results (Tim Penyusun Kamus Pusat Pembinaan dan Pengembangan Bahasa, 1996). Coaching has an understanding of the process of action, how to build, renewal, refinement, effort and action, actions that are carried out efficiently and effectively to obtain good results.

In the context of tertiary education, student development is interpreted as a learning process by providing knowledge, values and exemplary with the aim of helping and developing the skills and knowledge that students already have in order to gain skills and knowledge to achieve life goals.

The mandate of Law No. 20 of 2003 on National Education System is very clear that education in essence is to develop the potential of students based on faith and piety, personality, noble character, and independence. Thus, education has a strategic role in fostering and building student character. Because students are students in higher education, in order to achieve the objectives of national education, student guidance is needed, namely guiding all student activities as students during the education process.

\section{Islamic Academic Culture}

Islamic Academic Culture is the civilization of the application of Islamic values in all life on campus carried out by all campus residents to achieve educational goals at Unissula (Supadie et al., 2008). The implementation is in the form of activities with Islamic values as the basis of the entire academic and non-academic processes on campus which are carried out jointly and full of seriousness.

According to Unissula, the values of Islamic Academic Culture in general include two things, namely (1) strengthening of science and technology and (2) strengthening ruhiyah. Strengthening science and technology is intended to be an important part of campus life. Through Islamic Academic Culture, Unissula strives to improve scientific quality through strengthening science and technology. Strengthening science and technology is carried out through four things as follows: (a) Spirit of Iqra', (b) Developing science on the basis of islamic values, (c) Appreciation of science, and (d) building Islamic Learning Society.

Ruhiyah reinforcement is intended so that the faith and piety and akhlakul karimah (noble character) become the pillars that underlie someone in demanding knowledge and are able to practice it for the benefit of the universe. Ruhiyah reinforcement in Islamic Academic Culture includes the following: (a) Movement of congregational prayer, (b) Islamic dress 
movement, (c) Thaharah Movement, (d) Exemplary Movement, (e) Islamic Hospitality Movement, (f ) Movement to Realize Noble Morals.

\section{METHODS}

Data

Table 1. Data Needed

\begin{tabular}{ll}
\hline \multicolumn{1}{c}{ Data Needed } & \multicolumn{1}{c}{ Sources } \\
\hline Student coaching literature and Islamic & Article in journal, scientific magazines, \\
Academic Culture & text books etc \\
$\begin{array}{l}\text { General data of UNISSULA } \\
\text { Implementation of student development } \\
\text { programs based on Islamic Academic }\end{array}$ & $\begin{array}{l}\text { Profile of UNISSULA } \\
\text { Dulture }\end{array}$ \\
\hline
\end{tabular}

\section{Respondent}

The respondent of this study is students, dean, and faculty secretary of English Education Study Program.

\section{Data Collection}

Data collection in this study was conducted through interviews, observations, and questionnaires to the respondents.

\section{Data Analysis}

This analysis is used to analyze data and information obtained from preliminary studies. The use of qualitative descriptive analysis is intended to obtain an overview of the role of organizers and educators in the process of planning, implementing, and evaluating the development of UNISSULA English Language Education students.

\section{FINDINGS}

\section{Practical Overview of the Personality Development Model}

The personality development model of prospective teachers through student development based on Islamic Academic Culture is prepared based on Unissula's vision and mission. Efforts to realize a vision with Islamic Academic Culture as the basis for student development have become consensus and value commitments that have been built together. Building value commitment together in accordance with the principles of value-based management as stated by Robbin \& Coulter (2007) that a value-based management approach is a management approach by establishing, advancing, and practicing values with an organization. Shared values act as guidelines for managerial actions and decisions.

In Unissula, the implementation of student coaching as a translation of the coaching program begins when new students start entering through 
the Pekan Taaruf program. Then when entering the first and second semester lectures, students are required to take part in the Religious Tutorial activities. In semester 3 until before graduation students are given the freedom to participate in coaching activities in accordance with talent and specialization. Until finally, when students approach graduation, they are obliged to follow the debriefing activities of prospective graduates.

The management of student guidance from the beginning of admission to graduate students on an ongoing basis is in line with the opinion of Qomar (2007) that the management of students is management related to students starting from the beginning to completing (graduating) studies from educational institutions.

Unissula is committed to realizing the vision of building the generation of khaira ummah through the creation of Islamic campus communities by applying the values of the Qur'anic teachings and guidance of the Prophet Muhammad who are full of love and glory (Supadie, et al., 2008) through the application of Islamic Academic Culture. This culture is a movement of Islamic values within the campus that is carried out together and full of seriousness as a habit of living with values that are believed to be true, namely the application of Islamic values in the whole campus life (Supadie, et al., 2008).

Personality competency development through strengthening ruhiyah in Islamic Academic Culture means that prospective teacher students have a strong faith through the practice of consistent Islamic teachings (istiqamah), have good morals that can support their competence as prospective teachers. The intended development model can be described as follows.

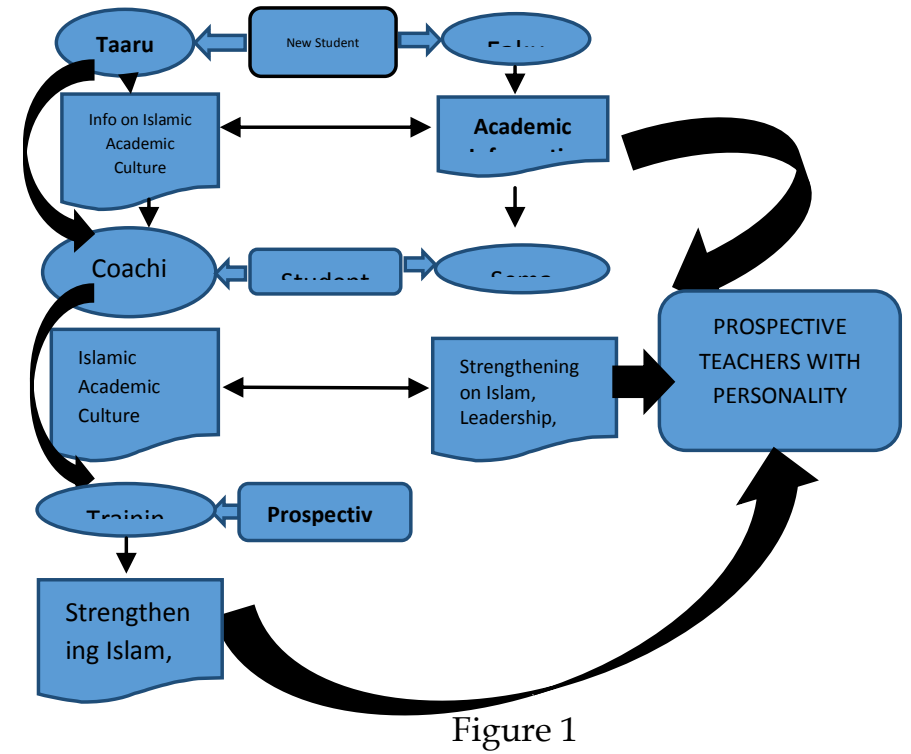

Model of Prospective Teacher Personality Competence Development 
Description of the application of aspects of ruhiyah reinforcement through Islamic Academic Culture as shown in figure 1 are as follows:

(a) Application of the congregational shalat movement

Shalat is the pillar of religion. The main shalat is congregational one. Shalat in congregation is a media to build the solidity of the community (Muslims). Congregational shalat is the representation of true worshipers in gathering themselves harmoniously to move forward towards the common goal.

Congregational shalat is held at Unissula as part of a strong affirmation in the implementation of Islamic Academic Culture. To succeed in the congregational prayer movement a Motivator Team is formed consisting of lecturers and employees as well as students. The motivator team is tasked with reminding them to carry out congregational prayers.

In addition, the provisions of all campus activities have stopped providing services at 11:45 a.m. and 14:45 a.m. The purpose is to stop campus activities so that all lecturers, employees and students carry out the jamah dhuhur and ashar prayers in the mosque.

(b) Application of the Islamic Dress Movement

Clothing is one of one's personal mirrors. Even the Javanese proverb mentions ajining salira ana ing busana, which means more or less one's selfesteem (personality) is located in the way and style of wearing a dress.

The basic rule that must be understood in dress is about the boundaries of genitals, both male genitals and female genitals (Tim Budai, 2008). In the framework of implementing Islamic Academic Culture in Islamic dress aspects, Unissula is applied in accordance with the Chancellor's Decree Number: 5812 / J / SA / XI / 2007. The application of Islamic dress culture in an effort to streamline its implementation, then for students who have not been dressed in Islamic regulations according to the provisions are not permitted to take classes and are not given service (Chancellor Rector Number: 5621 / J / SA / X / 2007)

(c) Application of Thaharah Movement

Maintaining purity and cleanliness (thaharah) is part of worship. Even in some ways thaharah is the key in carrying out worship to Allah SWT. For Muslims, implementing thaharah is part of the act of faith and as a key to worship that must be done seriously in order to get closer to worshiping Allah SWT. Thaharah does not stop at the realm of individual Muslims individually, but Islam also pays attention to cases of purity/cleanliness in the environment.

Consequently, it is imperative for every Muslim to be a pure and clean person, then jointly strive to form a holy and clean collective / pilgrimage to finally create a people who decorate society and the world with the beauty 
of a pure and clean life, through mastery of teaching disciplines and the practice of religious best practices in the Muslim community consistently.

The application of Islamic Academic Culture in the environmental aspects of the environment in addition to always maintaining the cleanliness of the campus is also done with a prohibition to smoke. Smoking is an action that can pollute the environment while it is also not healthy for the human body. The imposition of a smoking ban is stipulated in the Chancellor's Decree Number: 4654 / B.1 / SA / VIII / 2007.

\section{CONCLUSION}

Based on data analysis and discussion in this study, several conclusions can be drawn according to the formulation of the problem as follows:

1. The factual model that has been carried out by Unissula in fostering students based on the Unissula Strategic Plan (Renstra), and Islamic Academic Culture values through three stages of coaching, namely the initial stage when new students are trained through the Pekan Taaruf program, the second stage when becoming students coaching is done through tutorials, reasoning, leadership, entrepreneurship, and programs for developing interests and talents. In the third stage of coaching when students approach graduation, it is conducted through a debriefing program.

2. The development of a factual model is carried out by compiling student coaching concepts based on Islamic Academic Culture by referring to the Koran basis which is developed by describing the general analysis of student development problems, description of the development of student potential based on Islamic values contained in Al Quran as a basic framework student development patterns, elaboration of the main points of student development, a description of the stages of student development as a frame of reference for the stages of coaching according to capacity, semester level and achievement targets of the coaching program, and management coverage which are guidelines by implementing quality procedures.

3. Based on the results of the trial and development, the Student Academic Culture Based Islamic Development Management Model has proven to be effective as a model of student development based on Islamic Academic Culture in an effort to improve the quality of students. Efforts to improve quality are carried out through the taaruf week program as a program for students' initial introduction to campus life and mapping of student potential, religious tutorial programs, leadership and entrepreneurship programs, interest and talent development programs 
and briefing programs as the last program students receive before graduation.

4. Response of the management is in the very high category in the concept of conformity with Unissula's vision, mission, Islamic Academic Culture values, Unissula Strategic Plan (Renstra), systematic pattern and stages and substance content and student development programs, practicality of application of models in efforts to foster students and the effectiveness of the model towards student development.

\section{REFERENCES}

Abdurrahman. (2007). Kompetensi Kepribadian Guru. Bandar Lampung: Universitas Lampung Press.

Anwar, R. (2010). Risalah Bismillah Membangun Generasi Khaira Ummah. Semarang: Unissula Press.

Badan Narkotika Nasional (BNN). (2013). Data Tindak Pidana Narkotika Jawa Tengah Tahun 2007-2011. www.bnn.go.id accessed on 7 January 2013.

Badan Narkotika Nasional (BNN). (2013). Survey Nasional Perkembangan Penyalahgunaan dan Peredaran Gelap Narkoba Pada Kelompok Pelajar/Mahasiswa di Indonesia Tahun 2011. www.bnn.go.id accessed on 7 January 2013.

Dawson, C. (2010). The Crisis of Western Education. Washington, D.C.: The Catholic University of America Press.

Departemen Agama Republik Indonesia. (2010). Alquran dan Terjemahannya, Semarang: PT. Karya Toha Putra.

Irawan, P. (2010). Hubungan Persepsi terhadap Kompetensi Guru dengan Motivasi Berprestasi Siswa Kelas VII Smp Negeri 2 Tirto. Unpublished Thesis. Universitas Diponegoro Semarang.

Iswanti, S. (2017). Pembentukan Sikap dan Kepribadian Guru Melalui Model Pendidikan

Berasrama,

http://staff.uny.ac.id/sites/default/files/Artikel\%20pnelitian\%20as rama.pdf, accessed on 11 January 2017.

Lewis, H. (2006). Excellence Without a Soul: How a Great University Forgot Education, Public Affairs.

Nasikhah, D. (2013). Hubungan antara Tingkat Religiusitas dengan Perilaku Kenakalan Remaja pada Masa Remaja Awal. Jurnal Psikologi Pendidikan dan Perkembangan Volume 02, No. 01, Februari 2013, Universitas Airlangga, Surabaya.

Nuridin, (2015). The Development Model of Student Guidance Management Based on Islamic Academic Culture in UNISSULA, International Journal of Education and Research Vol. 3 No. 2 February 2015, https://www.ijern.com/journal/2015/February-2015/14.pdf.

Qomar, M. (2007). Manajemen Pendidikan Islam, Jakarta: Penerbit Airlangga. 
Ramayulis. (2008). Ilmu Pendidikan Islam. Jakarta: Kalam Mulia.

Robbin \& Coulter. (2007). Manajemen (edisi kedelapan). Jakarta: PT. Indeks.

Sardiman, A.M., (2007). Interaksi dan Motivasi Belajar Mengajar. Jakarta: PT. Raja Grafindo Persada.

Siagian, S.P. (1980). Falsafah Administrasi. Jakarta: CV. Masagung.

Simbolon, M. 2012. Perilaku Bullying pada Mahasiswa Berasrama, Jurnal Psikologi Vol. 39. No. 2. Desember 2012.

https://www.google.co.id/?gws_rd=ssl\#q=simbolon+penelitian+ke kerasan+mahasiswa+di+asrama

Moberly, S.W. (1949). The Crisis in the University. London: SCM Press Publisher. https://www.questia.com/library/533242/the-crisis-inthe university,

Rahayu, S. (2007). Kontribusi Kompetensi Kepribadian Guru PAI dalam Pengembangan Moral Siswa di MIN Karang Manis Juwiring Klaten. Unpublished thesis. Yogyakarta: Fakultas Tarbiyah UIN Sunan Kalijaga.

Statute of Unissula. (2011).

Sudradjat, A. (2015). Arti Penting Kompetensi Kepribadian Guru, https://akhmadsudrajat.wordpress.com/2012/10/22/kompetensikepribadian-guru/ dowloaded on 10 January 2015

Supadie, D. A. et al. (2008). Budaya Akademik Islami. Semarang: Unissula Press.

Terry, G. R. (2006). Prinsip-prinsip Manajemen. Jakarta: Bumi Aksara.

Tim Penyusun Kamus Pusat Pembinaan dan Pengembangan Bahasa. (1996). Kamus Besar Bahasa Indonesia. Jakarta: Balai Pustaka.

Undang-Undang Republik Indonesia (UU RI) No 20, 2003 on National Education System.

Undang-Undang Republik Indonesia (UU RI) No 14, 2005 on Teacher and Lecturer

Wahab, A. \& Umiarso (2011). Kepemimpinan Pendidikan dan Kecerdasan Spiritual. Yogyakarta: Ar-Ruzz Media. 